\title{
Studi Budaya Dalam Komunitas Fans Nike Ardilla di Jakarta (Fanatisme Penggemar Nike Ardilla)
}

\author{
Stella, Suzy S. Azeharie \\ Angelinstella01@yahoo.com, suzya@fikom.untar.ac.id
}

Fakultas Ilmu Komunikasi Universitas Tarumanagara

\begin{abstract}
Nike Ardilla Fans Club as well as nickname for a group of people who like a singer named Nike Ardilla, has a lot of common according to Nike Ardilla. There are some of Nike Ardilla fans from other country beside Indonesia which are Malaysia, Brunei Darussalam, Singapore, Thailand, and Hongkong. The purpose of this research is to find out the cultural communication studies in Nike Ardilla Fans Club at Jakarta. Also to find out what kind of fanatism of Nike Ardilla fans (community) and lastly this research wants to find out the reasons why they love Nike Ardilla so much. The theory for this research including communication theory, cultular theory, fanatism theory, and cultural identity theory. The research method used is qualitative research method of case study descriptively. The data of this research are coming from interviews with the key informan and also because of the observation on field. The conclusion of this research are the community of Nike Ardilla Fans Club is most of her fans are girls. And every of them have some reason why they became so fanatic. The community has the culture identity which is some unique tradition that make their bond even stronger than before. They also using social media to keep in touch to each other.
\end{abstract}

Keywords: Nike Ardilla, Nike Ardilla Fans Club, Fanatism, Communication and Cultural Identity

\begin{abstract}
Abstrak
Nike Ardilla Fans Club merupakan sebuah nama bagi penggemar dari penyanyi Nike Ardilla yang terdiri dari berbagai macam orang yang memiliki ketertarikan yang sama. Nike Ardilla Fans Club sudah tersebar hampir di seluruh provinsi di Indonesia. Penggemar Nike Ardilla juga tersebar di luar negeri seperti Malaysia, Brunei Darussalam, Singapura, Thailand dan Hongkong. Penelitian ini dibuat untuk mengetahui studi komunikasi budaya dalam komunitas fans Nike Ardilla di Jakarta, untuk mengetahui bentuk fanatisme komunitas fans Nike Ardilla dan untuk mengetahui komunitas fans Nike Ardilla menjadi fanatik. Teori yang digunakan dalam penelitian ini adalah teori komunikasi, teori budaya, teori fanatisme dan teori identitas budaya. Metode penelitian yang digunakan adalah metode penelitian kualitatif studi kasus secara deskriptif. Data yang dianalisis diperoleh dari hasil wawancara dengan narasumber dan dari hasil observasi. Penelitian ini menunjukkan bahwa komunitas Nike Ardilla fans Club didominasi oleh anggota perempuan. Anggota Nike Ardilla Fans Club memiliki alasan tertentu yang membuat para fans menjadi fanatik. Komunitas Nike Ardilla Fans Club memiliki identitas budaya yaitu kebiasaan unik yang dilakukan sehingga membentuk budaya yang terjadi sampai saat ini, dan komunikasi yang terjalin antara sesama anggota Nike Ardilla Fans Club berjalan dengan baik. Komunikasi yang dilakukan juga menggunakan perantara media sosial .
\end{abstract}

Kata Kunci: Nike Ardilla Fans Club, Fanatisme, Komunikasi dan Identitas Budaya 


\section{Pendahuluan}

Manusia mengenal budaya melalui proses komunikasi. Sebab budaya itu sifatnya dipelajari. Budaya menurut Larry A. Samovar dan Richard E. Porter dalam buku Alo Liliweri yang berjudul Komunikasi Serba Ada Serba Makna, adalah simpanan akumulatif dari pengetahuan, pengalaman, kepercayaan, nilai, sikap, makna, hirarki, agama, pilihan waktu, peranan, relasi ruang, konsep yang luas dan objek material atau kepemilikan yang dimiliki dan dipertahankan oleh sekelompok orang atau suatu generasi (Liliweri, 2011).

Komunikasi merupakan kebutuhan dasar manusia. Menurut Stewart L. Tubbs dan Sylvia Moss dalam buku yang berjudul Human Communication Prinsip-Prinsip Dasar menyatakan komunikasi dikatakan sebagai proses pembentukan makna di antara dua orang atau lebih (Tubbs dan Moss, 2005). Manusia dan komunikasi saling mempengaruhi satu dengan lainnya. Hal ini sejalan dengan apa yang dikatakan oleh Wilbur Schramm dalam buku H. Hafied Cangara yang berjudul Pengantar Ilmu Komunikasi bahwa komunikasi dan masyarakat adalah dua kata kembar yang tidak dapat dipisahkan satu sama lainnya. Tanpa komunikasi masyarakat tidak dapat terbentuk begitu pula sebaliknya, tanpa masyarakat maka komunikasi tidak dapat berkembang (Cangara, 2012).

Di tempat lain Ngalimun dalam buku Ilmu Komunikasi Sebuah Pengantar Praktis mengatakan komunikasi dan budaya dapat diibaratkan dengan dua sisi mata uang yang tidak terpisahkan dan saling mempengaruhi. Budaya menentukan peran para pelaku komunikasi dan menjadi media penafsir isi pesan di antara para komunikan. Komunikasi manusia menurut Ngalimun dapat saling berbagi informasi, bertukar informasi dan mengembangkan diri. Selain itu dengan berkomunikasi manusia dapat mengungkapkan perasaan, emosi, pemikiran dan gagasan (Ngalimun: 2017). Umumnya kelompok masyarakat yang menganut nilai-nilai budaya tertentu dapat ditemukan dalam sebuah komunitas. Komunitas atau masyarakat setempat menurut Soerjono Soekanto dalam buku Slamet Santoso dalam buku yang berjudul Dinamika Kelompok, merujuk pada sebuah desa, sebuah kota, suku, atau suatu bangsa (Santoso, 2004). Sementara Yosal Iriantara dalam buku Manajemen Strategis Public Relations mengatakan komunitas merupakan sekumpulan individu yang mendiami lokasi tertentu dan anggotanya saling berkaitan karena memiliki kepentingan yang sama (Iriantara, 2004).

Nike Ardilla Fans Club merupakan salah satu fans yang tetap bertahan. Raden Rara Nike Ratnadilla Kusnadi atau dikenal dengan Nike Ardilla anak dari pasangan R Eddy Kusnadi dan Nining Ningshirat yang merupakan artis legendaris Indonesia yang telah menunjukan bakatnya sejak masih kecil. Nike Ardilla lahir pada tanggal 27 Desember 1975 pada usia lima tahun, Nike Ardilla sudah tampil di acara televisi nasional. Nike Ardilla Fans Club merupakan kumpulan orang-orang yang mencintai sosok penyanyi Nike Ardilla beserta karya yang telah dihasilkan Nike Ardilla. Awal mula terbentuknya fans club tersebut sebagai bentuk dukungan dan cinta kepada Nike Ardilla. Namun pada tanggal 19 Maret 1995 Nike Ardilla meninggal dunia.

Nike Ardilla Fans Club pertama kali berdiri tanggal 09 September 1990. Menurut hasil wawancara penulis dengan Emma Amrin ketua dari Nike Ardilla Fans Club Indonesia, hingga saat ini Nike Ardilla Fans Club telah tersebar di seluruh Indonesia dan manca negara seperti Belanda, Jepang, Malaysia, Singapura dan Brunei Darussalam. Kesetiaan Nike Ardilla Fans Club dapat dilihat melalui fenomena fanatisme yang terjadi pada sebagian penggemar Nike Ardilla. Salah satu 
contohnya adalah ketika label rekaman mengeluarkan album kompilasi Nike Ardilla dan ditawarkan kepada Nike Ardilla Fans Club langsung habis terjual. Meskipun hanya berbeda sampul kaset namun isi lagu tetap sama, anggota Nike Ardilla Fans $C l u b$ tetap membelinya. Fenomena fanatisme merupakan bukti nyata dari bentuk kecintaan fans terhadap sosok yang diagungkan yakni penyanyi Nike Ardilla.

Penulis tertarik mengangkat penelitian mengenai studi budaya dalam komunitas fans Nike Ardilla di Jakarta dan fanatisme yang terjadi pada fans Nike Ardilla. Alasan penulis memilih Nike Ardilla Fans Club untuk diteliti karena komunitas fans Nike Ardilla merupakan fans club yang tetap bertahan hingga saat ini dan relatif setia mendukung segala bentuk karya yang telah dihasilkan oleh Nike Ardilla selama hidupnya.

Rumusan masalah ini adalah bagaimana komunikasi budaya dalam komunitas fans Nike Ardilla di Jakarta dan bagaimana bentuk fanatisme komunitas fans Nike Ardilla serta membahas mengapa komunitas fans Nike Ardilla menjadi fanatik. Tujuan Penelitian ini adalah berharap penelitian ini dapat memberikan informasi untuk mengetahui komunikasi budaya yang terbentuk pada komunitas fans Nike Ardilla di Jakarta dan juga dapat menambah informasi mengenai bentuk fanatisme yang terjadi pada komunitas fans Nike Ardilla di Jakarta.

\section{Metode Penelitian}

Pada penelitian ini penulis menggunakan metode penelitian kualitatif secara deskriptif. Menurut Supardi dalam bukunya yang berjudul Metodologi Penelitian Ekonomi dan Bisnis menyatakan bahwa metode kualitatif sebagai prosedur penelitian yang menghasilkan data deskriptif berupa kata-kata tertulis atau lisan dari orang-orang atau perilaku yang dapat diamati. Penelitian deskriptif menurutnya adalah suatu metode penelitian yang menggambarkan semua data atau keadaan subjek atau objek penelitian kemudian dianalisis dan dibandingkan berdasarkan kenyataan yang sedang berlangsung saat ini dan selanjutnya mencoba untuk memberikan pemecahan masalahnya dan informasi yang mutakhir sehingga bermanfaat bagi perkembangan ilmu pengetahuan serta lebih banyak dapat diterapkan pada berbagai masalah (Supardi, 2005).

Lexy J. Moleong dalam buku Metodologi Penelitian Kualitatif menambahkan analisis data kualitatif adalah upaya yang dilakukan dengan jalan bekerja dengan data, mengorganisir data dan memilah-milahnya menjadi satuan yang dapat dikelola selain itu mensistensikannya, mencari, menemukan pola, menentukan yang penting, dipelajari, dan memutuskan apa yang dapat diceritakan kepada orang lain (Moleong, 2012). Dalam hal ini penulis melakukan teknik pemeriksaan keabsahan data dalam penelitian ini menggunakan triangulasi. Menurut Lexy J. Moleong dalam bukunya yang berjudul Metodologi Penelitian Kualitatif mengatakan bahwa triangulasi adalah teknik pemeriksaan keabsahan data yang memanfaatkan sesuatu yang lain. Pada dasarnya triangulasi merupakan cara terbaik untuk menghilangkan perbedaanperbedaan konstruksi kenyataan yang ada dalam konteks suatu studi sewaktu mengumpulkan data tentang berbagai kejadian dan hubungan dari berbagai pandangan. Dengan kata lain triangulasi memeriksa temuannya dengan jalan membandingkannya dengan berbagai sumber, metode dan teori sehingga pembaca memperoleh informasi yang jelas tentang temuan penelitian (Moleong, 2009). Dalam penelitian ini penulis memilih metode kualitatif bersifat deskriptif dengan pendekatan fenomenologi karena penulis ingin meneliti bagaimana komunikasi 
budaya yang terbentuk dalam komunitas fans Nike Ardilla. Metode penelitian deksriptif ini memungkinkan penulis untuk melakukan pengamatan secara mendalam sehingga menemukan masalah dan menganalisis hasil dari penelitian ini.

\section{Hasil Temuan dan Diskusi}

Berdasarkan hasil wawancara penulis dengan Emma Amrin selaku ketua dari Nike Ardilla Fans Club tahun 1990 pertama kali namanya hanya Nike Ardilla Fans, tetapi setelah Nike Ardilla meninggal di Bandung pada 19 Maret 1995 dibentuklah Nike Ardila Fans Club di daerah fans masing-masing. Nike Ardilla Fans Club terbesar ada di Jabodetabek didirikan tahun 1995 berawal ketika Nike Ardilla meninggal dunia dan banyak diliput di media cetak. Saat pemakaman Nike Ardilla di Ciamis, fans berkumpul di kuburannya dan mereka mengambil keputusan bersama untuk membentuk Nike Ardilla Fans Club Jabodetabek.

Tidak ada syarat khusus untuk menjadi anggota dari Nike Ardilla Fans Club, asalkan mempunyai kecintaan terhadap Nike Ardilla dan karya-karyanya saja sudah cukup. Tidak ada juga kartu keanggotaan bagi anggota Nike Ardila Fans Club. Mereka yang sudah tergabung menjadi anggota Nike Adilla Fans Club akan diundang masuk dalam grup Facebook resmi dengan nama Nike Ardilla Fans Club Indonesia. Tidak ada iuran wajib bagi anggota Nike Ardilla Fans Club. Iuran ada jika akan dibuat suatu kegiatan, yang akan hadir dalam acara itu diwajibkan membayar sejumlah uang yang sudah disepakati bersama sesuai dengan kebutuhan.

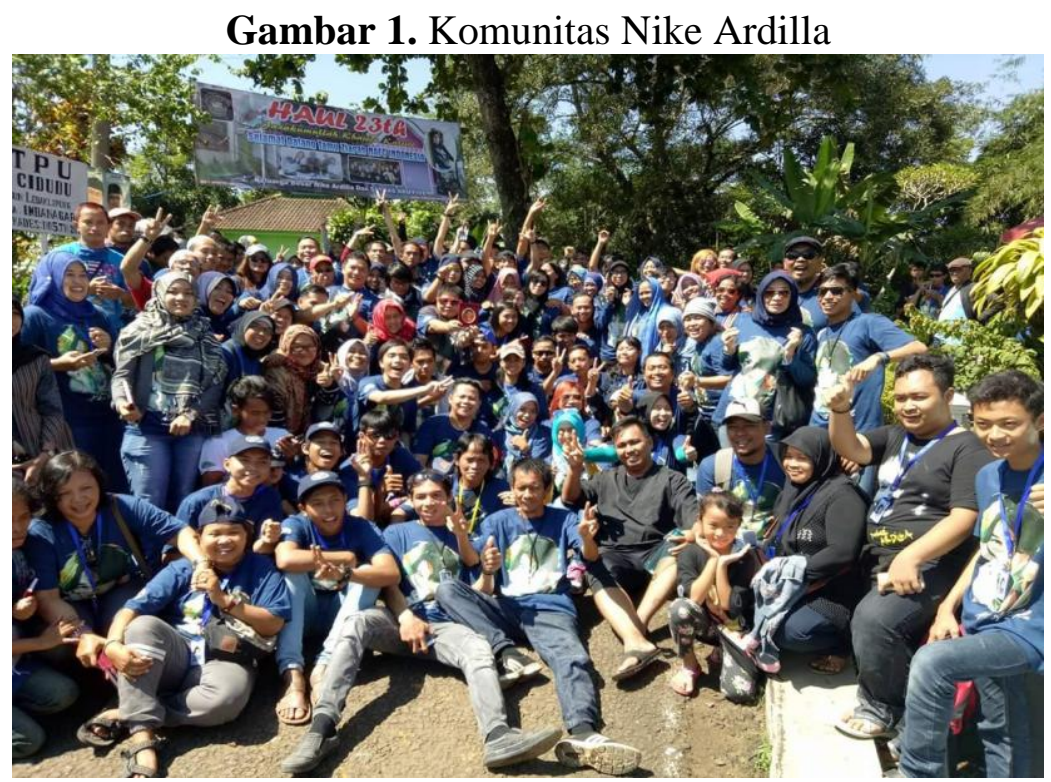

Sumber: Dokumentasi Anna Trisnawati

Menurut beberapa informan bentuk dari fanatisme komunitas ada berbagai macam, setiap penggemar mempunyai bentuk fanatisme yang berbeda-beda. Ada anggota yang selalu ikut serta dalam acara Nike Ardilla Fans Club. Ada yang mengumpulkan barang yang berhubungan dengan Nike Ardilla seperti majalah, kaset, ataupun hanya poster Nike Ardilla.

Selain itu menurut salah satu fans dari Nike Ardilla Fans Club bentuk fanatisme komunitas adalah dengan mengajukan permohonan kepada keluarga Nike Ardilla untuk dibuatkan Museum Nike Ardilla, sehingga penggemar dapat 
berkumpul untuk mengenang Nike Ardilla melalui barang-barang yang dikenakan saat Nike Ardilla masih hidup. Di Museum Nike Ardilla selain terdapat peninggalan Nike Ardilla, ada juga sudut untuk menjual suvenir. Para fans yang datang ke Museum biasanya membeli barang yang dijual misalnya poster Nike Ardilla, baju bergambar wajah Nike Ardilla, bantal, gantungan kunci dan gelas. tujuan membeli suvenir antara lain untuk kepuasan pribadi, dan juga secara tidak langsung dengan menyumbangkan bantuan untuk biaya perawatan Museum Nike Ardilla

Bentuk komunikasi dalam Nike Ardilla Fans Club adalah berjumpa langsung melalui pertemuan rutin yang diadakan satu kali setiap bulan pada minggu pertama bulan tersebut. Pertemuan ini dihadiri oleh pengurus Nike Ardilla Fans Club, biasanya yang hadir antara 8 sampai 15 orang. Pertemuan rutin biasanya diadakan di rumah Emma Amrin selaku ketua Nike Ardilla Fans Club, atau bisa juga di kafe dan restoran sesuai dengan kesepakatan bersama. Dalam pertemuan itu membahas tentang masalah-masalah yang dihadapi komunitas Nike Ardilla Fans Club umum maupun masalah-masalah yang terjadi antar anggota secara khusus. Dalam pertemuan rutin ini juga membahas tentang kegiatan komunitas Nike Ardilla Fans $C l u b$ yang akan berlangsung. Dalam pertemuan tersebut juga membahas masalah dalam komunitas Nike Ardilla Fans club, masalah yang muncul akibat perbedaan budaya masing-masing anggota harusnya dapat diselesaikan dengan baik karena kecintaan terhadap Nike Ardilla yang mempersatukan komunitas ini.

Hal unik yang menjadi identitas budaya Nike Ardilla Fans Club adalah dengan menyebarkan kebaikan dan jiwa sosial dari Nike Ardilla untuk menhilangkan pandangan negatif masyarakat terhadap sosok Nike Ardilla. Pandangan negatif masyarakat bahwa Nike Ardilla adalah anak nakal yang suka merokok, minum minuman keras dan bahkan terlibat narkoba coba dipatahkan oleh komunitas Nike Ardilla Fans Club melalui kegiatan amal, pengumpulan dana dan bakti sosial.

Nike Ardilla Fans Club merasa hal positif yang dilakukan oleh Nike Ardilla merupakan suatu hal yang patut untuk ditiru oleh mereka guna mengenang jiwa sosial Nike Ardilla semasa hidupnya. Menurut Fieka Minoru salah satu informan hal unik yang menjadi identitas budaya Nike Ardilla Fans Club adalah berawal dari adanya kesamaan tujuan berdirinya Nike Ardilla Fans Club yaitu memiliki tanggung jawab serta jiwa sosial yang sama seperti sosok dari Nike Ardilla itu sendiri. Selain itu juga dengan mengadakan rapat untuk mengadakan suatu kegiatan amal yang berguna untuk membantu sesama. Identitas budaya Nike Ardilla Fans Club juga dapat dilihat melalui kesamaan akan gaya busana dan model rambut Nike Ardilla pada saat menghadiri suatu acara yang berkaitan dengan Nike Ardilla. Tidak pandang laki-laki atau perempuan semua berdandan seperti Nike Ardilla dengan gaya rambut belah tengah khasnya atau gaya rambut pendek diatas bahu. Dalam berpakaian juga meniru gaya Nike Ardilla dengan baju terusan, kaos, dan kemeja.

Emma Amrin selaku ketua dari Nike Ardilla Fans Club menambahkan bahwa untuk mempertahankan identitas budaya komunitas Nike Ardilla Fans Club dapat dilakukan melalui ikatan persaudaraan yang solid antara anggota. Anggota Nike Ardilla Fans Club menyelesaikan masalah dan perbedaan pendapat melalui kesepakatan bersama sehingga dapat menemukan solusi dan Nike Ardilla Fans Club tetap terus bertahan. Selain itu juga para fans di setiap daerah tetap menjalin hubungan komunikasi antara satu dengan yang lainnya.

Komunikasi yang digunakan dalam Nike Ardilla Fans Club terjadi secara verbal maupun nonverbal. Komunikasi verbal dapat terjadi dalam kegiatan-kegiatan yang dilakukan oleh Nike Ardilla Fans Club misalnya komunikasi ketika acara rutin 
berkumpul di daerah masing-masing anggota. Berdasarkan analisis penulis terhadap narasumber terdapat kesamaan dengan teori yang menjadi landasan penulis dalam melakukan penelitian seperti diungkapkan Deddy Mulyana dalam buku Ngalimun yang berjudul Ilmu Komunikasi Sebuah Pengantar Praktis, mengungkapkan bahwa bahasa dapat juga dianggap sebagai sistem kode verbal (Ngalimun, 2017).

Emma Amrin sebagai ketua dari Nike Ardila Fans Club seluruh Indonesia mengatakan budaya yang ada di Nike Ardilla Fans Club yang masih ada sampai saat ini adalah rutinitas dalam merayakan acara ulang tahun Ibunda Nike Ardilla dan ziarah ke makam Nike Ardilla untuk merayakan hari kelahiran setiap tanggal 27 Desember dan pada saat hari kematian setiap tanggal 19 Maret. Kegiatan ziarah merupakan kegiatan rutin yang menurut Emma tanpa diajak atau diberi tahu terlebih dahulu, anggota Nike Ardila Fans Club dengan sadar selalu melakukannya.

Berdasarkan analisa penulis bahwa budaya merupakan kepercayaan, nilai dan sikap yang lahir dari proses interaksi yang diperoleh sekelompok besar orang dari generasi ke generasi melalui usaha individu dan kelompok. Hubungannya dengan penelitian yang dilakukan penulis bahwa Nike Ardilla Fans Club merupakan sekelompok orang yang sama-sama memiliki nilai seni dan kekeluargaan yang tinggi serta sikap saling menghargai dan menghormati antar anggota komunitas Nike Ardilla Fans Club.

Menurut informan tentang terbentuknya fanatisme yang terjadi dalam Nike Ardilla Fans club. Anggota terdiri dari latar belakang pekerjaan yang berbeda, latar pendidikan yang berbeda namun mempunyai satu idola yang sama yaitu Nike Ardilla. Ketertarikan masing-masing anggota Nike Ardilla Fans club kepada sosok Nike Ardilla pada satu titik menunjukan kesamaan yaitu menyukai sikap dermawan terhadap Nike Ardilla. Menurut mereka walaupun sukses dalam usia yang relatif muda, Nike Ardilla tidak lupa untuk berbuat baik kepada lingkungannya, hal itu dibuktikan dengan membangun sebuah Sekolah Luar Biasa di lingkungan dekat rumahnya. Dapat dirangkumkan bahwa fanatisme merupakan sebuah keadaan di mana sekelompok orang yang terobsesi akan suatu hal yang sama sehingga menimbulkan rasa kecintaan yang besar terhadap sosok tersebut.

Hubungannya dengan penelitian yang dilakukan penulis bahwa Nike Ardilla Fans Club merupakan salah satu bentuk dari fanatisme yang memang terjadi pada sekelompok orang. Dengan begitu Nike Ardilla Fans Club mempunyai identitas sendiri yang berbeda di mata orang lain. Selain itu juga yang menjadi identitas budaya Nike Ardilla Fans Club adalah berawal dari adanya kesamaan tujuan dari berdirinya Nike Ardilla Fans Club yaitu memiliki tanggung jawab serta jiwa sosial yang sama seperti sosok dari Nike Ardilla itu sendiri.

\section{Simpulan}

Nike Ardilla Fans club merupakan sebuah nama bagi penggemar penyanyi poprock yaitu Nike Ardilla yang terdiri dari berbagai golongan mulai dari anak-anak muda bahkan sampai orangtua yang berasal dari berbagai daerah di Indonesia. Nike Ardilla Fans Club terbentuk karena adanya kesamaan kegemaran yaitu menyukai penyanyi Nike Ardilla. Nike Ardilla Fans Club sudah tersebar hampir di seluruh provinsi di Indonesia, selain itu juga para penggemar Nike Ardilla juga sudah tersebar di luar negeri seperti Malaysia, Brunei Darussalam, Singapura, Thailand dan Hongkong. Saat ini jumlah anggota Nike Ardilla Fans Club kurang lebih 20.000 
orang yang aktif di seluruh Indonesia dengan persentase perempuan $70 \%$ dan lakilaki $30 \%$.

Bentuk fanatisme yang ada di dalam Nike Ardilla Fans Club sangat beragam dimulai dari anggota Nike Ardilla Fans Club yang mengoleksi majalah-majalah yang membahas Nike Ardilla, kaset-kaset dari semua album Nike Ardilla, atau poster Nike Ardilla. Identitas budaya yang masih ada sampai saat ini dalam Nike Ardilla Fans $C l u b$ adalah dengan teguh berpegang pada tujuan berdirinya Nike Ardilla Fans Club yaitu memiliki tanggung jawab serta jiwa sosial yang sama seperti sosok dari Nike Ardilla itu sendiri.

Nike Ardilla Fans Club berkomunikasi secara langsung melalui kegiatan rutin berkumpul sebulan sekali di daerah masing-masing, dan secara tidak langsung yaitu dengan media sosial seperti WhatsApp, Instagram, dan Facebook yang digunakan untuk berkomunikasi dengan anggota Nike Ardilla Fans Club yang berada di luar daerah lainnya agar tetap terjalin hubungan yang baik.

\section{Ucapan Terima Kasih}

Penulis mengucapkan terima kasih kepada Dra. Suzy S. Azeharie, M.A., M.Phil. selaku dosen pembimbing, kedua orang tua, key informant dan narasumber yang telah meluangkan waktunya serta teman-teman yang telah memberikan dukungan dan bantuan kepada penulis selama proses penyusunan skripsi.

\section{Daftar Pustaka}

Cangara, Hafield. (2012). Pengantar Ilmu Komunikasi. Jakarta: PT RajaGrafindo Persada

Iriantara, Yosal. (2004). Manajemen Strategis Public Relations. Jakarta: Ghalia

Liliweri, Alo. (2011). Komunikasi Serba Ada Serba Makna. Jakarta: Prenada Media Group

Moleong, Lexy J. (2012). Metodologi Penelitian Kualitatif. Bandung: PT Remaja Rosdakarya

Ngalimun. (2017). Ilmu Komunikasi Sebuah Pengantar Praktis. Yogyakarta: Pustaka Baru Press

Santoso, Slamet. (2004). Dinamika Kelompok. Jakarta: Bumi Aksara

Supardi. (2005). Metodologi Penelitian Ekonomi dan Bisnis.Yogyakarta: UII Press

Tubbs, Stewart L., \& Moss Sylvia. (2005). Human Communication: Prinsip-Prinsip Dasar. Bandung: PT. Remaja Rosdakarya 